\title{
Combining clinical features and MEST-C score in IgA nephropathy may be a better determinant of kidney survival
}

\author{
HASAN HACI YETER ${ }^{1}$, IPEK GONUL ${ }^{2}$, GIZEM GUZ ${ }^{3}$, OZANT HELVACI ${ }^{4}$, BERFU KORUCU ${ }^{1}$, \\ OMER FARUK AKCAY ${ }^{1}$, ULVER DERICI ${ }^{1}$, TURGAY ARINSOY ${ }^{1}$ \\ ${ }^{1}$ Department of Nephrology, Gazi University, Ankara, Turkey \\ ${ }^{2}$ Department of Pathology, Gazi University, Ankara, Turkey \\ ${ }^{3}$ Internal Medicine, Gazi University, Ankara, Turkey \\ ${ }^{4}$ Yildirim Beyazit University Yenimahalle Education and Research Hospital, Ankara, Turkey
}

\begin{abstract}
Introduction. $\operatorname{IgA}$ nephropathy $(\operatorname{Ig} \mathrm{AN})$ is a heterogeneous disease with highly variable clinical and histopathological features. We investigated the effects of Oxford classification and clinical features on renal survival in patients with IgAN.

Methods. This retrospective observational study conducted from 2013 to 2017 . Ninety-seven patients who were followed up more than six months were examined.

Results. A total of 97 patients ( $68 \%$ male and median age 40 years) were enrolled in this study. $13 \%$ of patients developed end stage renal disease (ESRD) within the median of 37 months of follow-up. Need for renal replacement therapy at the time of diagnosis, serum creatinine level of higher than $1.97 \mathrm{mg} / \mathrm{dl}$, serum albumin level less than $3.5 \mathrm{gr} / \mathrm{dl}$, 24-hour urine protein level of higher than $>3.5 \mathrm{~g} /$ day, the percentage of glomerulosclerosis higher than 53\%, T2 score and total MEST-C score higher than two were found to be significant predictors of development of ESRD. None of the clinical or histopathological features were found to be significant predictor of steroid treatment sensitivity except T1-2 scores.

Conclusion. We think that IgA nephropathy is a heterogeneous disease that requires clinical and histopathological features to be evaluated together, but not individually, to determine renal survival.

What is new. Iga nephropathy is a heterogeneous disease and modern pathologic classification systems is not enough to predict to prognosis. Histopathological features to be evaluated with clinical features, but not individually, to determine renal survival. Also glucocorticoid treatment response seems to be independent from clinical and histopathological features except T1-2 score.
\end{abstract}

Key words: IgA nephropathy, glomerulonephritis, end stage kidney disease, glucocorticoid, Oxford classification.

\section{INTRODUCTION}

Immunoglobulin A nephropathy (IgAN) is the most common primary glomerulonephritis in the world and its frequency is highest among Asians [1]. It is a heterogeneous disease with highly variable clinical presentation and end stage renal disease (ESRD) development risk ranges from $10 \%$ to $60 \%$ within ten years [2].

There are several clinical risk factors, including proteinuria and estimated glomerular filtration rate (eGFR) at the biopsy time, as predictors of poor prognosis [3]. Such others that have variable and controversial associations with renal outcome across different studies include patients' age, sex, race and the severity of hematuria [4]. Recently, Oxford classification was proposed to predict renal outcome by the International IgA Nephropathy Network in collaboration with the Renal Pathology Society in 2009 and the classification was updated in $2017[5,6]$. Original classification identified four histopathological features important for predicting the prognosis of IgAN: mesangial hypercellularity (M0-M1), endocapillary proliferation (E0-E1), segmental glomerulosclerosis (S0-S1), tubular atrophy/ interstitial fibrosis (T1-T2). The combined maximal score of this classification (MEST score) was 5 points (M1+E1+S1+T2) and renal lesions with a sum score of two or higher were accepted as having an independent risk factor for progression to ESRD for IgAN patients [7]. In addition, each of these 4 separate lesions was proposed as having an independent value as a risk factor for progression to ESRD [8]. S1 lesion was found to be associated with the presence of higher proteinuria levels and better response to immunosuppressive treatment [9]. In 2016, the classification was updated, and the presence of crescent formation $(\mathrm{C} 0-\mathrm{C} 1-\mathrm{C} 2)$ was added to the previous lesions described and the maximum sum score of the classification was up-graded to 7. The validity of MEST-C score for predicting ESRD development has been demonstrated by previous studies $[10,11]$. 
Several drugs, including inhibitors of renin-angiotensin-aldosterone (RAAS) system, antihypertensives or corticosteroids have been used as a therapeutic approaches to IgAN [12]. The Kidney Disease Improving Global Outcomes (KDIGO) guidelines recommends corticosteroid treatment for 6 months in the presence of persistently high proteinuria that does not improve for 3 to 6 months of supportive therapy. [13]. Almost all studies in the literature reported that corticosteroid therapy reduces the urinary protein leakage, however, there is no clinically relevant evidence of an improvement in renal survival $[14,15]$.

In this study, we aimed to investigate the clinical and histopathological features of IgAN, which may constitute a risk factor for the development of chronic renal failure and may determine the corticosteroid response.

\section{MATERIALS AND METHODS}

\section{STUDY POPULATION AND CORTICOSTEROID TREATMENT}

This retrospective study was conducted in Nephrology Department. Renal biopsy patients, older than $>18$ years of age and who were diagnosed with IgAN between 2012 and 2017 were included in the study. A total of 1273 renal biopsy records were re-scanned and 162 patients with biopsy characteristics that full-filled the diagnostic criteria of IgAN were selected. Patients with a follow-up of less than 6 months (55 patients), patients without a MEST-C score in their pathology reports, and patients with previous renal transplantation (10 patients) and patients with ESRD at the time of admission were excluded from the study. Finally, we analyzed the data of 97 patients with IgAN.

All these patients were given supportive care with full dose angiotensin converting enzyme inhibitor (ACEi) or angiotensin receptor blocker (ARB) to achieve target blood pressure according to KDIGO guideline and $1 \mathrm{mg} / \mathrm{kg} /$ day prednisone daily, which was tapered down within 6 months. [12] A total of 45 patients received another immunosuppressive therapy such as cyclophosphamide, cyclosporine, mycophenolate mofetil and tacrolimus in combination with glucocorticoids, and/or were given only supportive therapy for ESRD at the time of diagnosis. In addition, some patients could not be given an optimized corticosteroid therapy since they could not tolerate the side effects of the drug. Therefore, we only included the 52 patients' clinical and histopathological data in our statistical analysis, who were given standard KDIGO treatment, to determine the factors affecting the corticosteroid response in IgAN.
AKI was defined according to the 2012 Kidney Disease Improving Global Outcomes (KDIGO) clinical practice guideline for acute kidney injury as follows: increase in serum creatinine by $\geq 0.3 \mathrm{mg} / \mathrm{dl}$ within 48 hours or increase in serum creatinine to $\geq 1.5$ times baseline.

\section{DATA COLLECTION}

Hospital's electronic medical records system was used for baseline information such as patients' sex, age and need for renal replacement treatment (RRT) at the time of diagnosis. Total follow-up time and development of ESRD in follow-up were determined for all patients. Data regarding serum creatinine, albumin, blood urea nitrogen (BUN), estimated glomerular filtration rate (eGFR) and 24-hour urine protein levels were collected. We used the abbreviated The Chronic Kidney Disease Epidemiology Collaboration equation (CKD-EPI) to estimate GFR. Patients' serum creatinine, BUN, GFR, albumin and 24-hour urine protein levels were recorded at the time of diagnosis, at the 6 months, at the 12 months and at the last visit of follow-up.

Fresh biopsy cores had been divided under the microscope for light microscopy and immunofluorescence microscopy. Following fixation in buffered formalin and routine tissue processing, paraffine embedded, $2-3 \mu \mathrm{m}$ sections had been stained with hematoxylin eosin, Congo red, Masson's trichrome, Periodic acid-Schiff (PAS), Periodic acidmethenamine silver (Jones) stains. Immunofluorescence had been performed on unfixed, cryostat sections of kidney biopsy transported to the pathology laboratory on saline-soaked gauze. Fluorescein-labeled antibodies against immunoglobulins (IgG, IgM, IgA), complement components $(\mathrm{C} 3, \mathrm{C} 4, \mathrm{Clq})$ and, kappa and lambda light chains had been used. All renal biopsy specimens were re-assessed light microscopically by a nephropathologist blinded to patients according to updated Oxford classification (Figure 1) [10]. The study protocol conformed to ethical guidelines of the 1975 declaration of Helsinki and all participants gave written informed consent and willingness to participate.

\section{STUDY OUTCOMES}

Primary outcome of our study is to determine the risk of ESRD [eGFR less than $15 \mathrm{ml}$ per minute per $1.73 \mathrm{~m}^{2}$ ] development for patients with IgAN. We also aimed to investigate the effect of patients' demographics, clinical findings, laboratory markers and kidney biopsy findings (MEST-C score, 
immunofluorescence staining of $\mathrm{C} 3$ and monoclonal kappa and lambda staining) on prognosis of disease in these patients. Complete and partial response criteria to corticosteroid treatment were determined as follows; The presence of less than $\leq 500 \mathrm{mg}$ /day urine protein during follow-up was accepted as complete remission. $>50 \%$ reduction in urine protein during follow-up was accepted as partial remission.

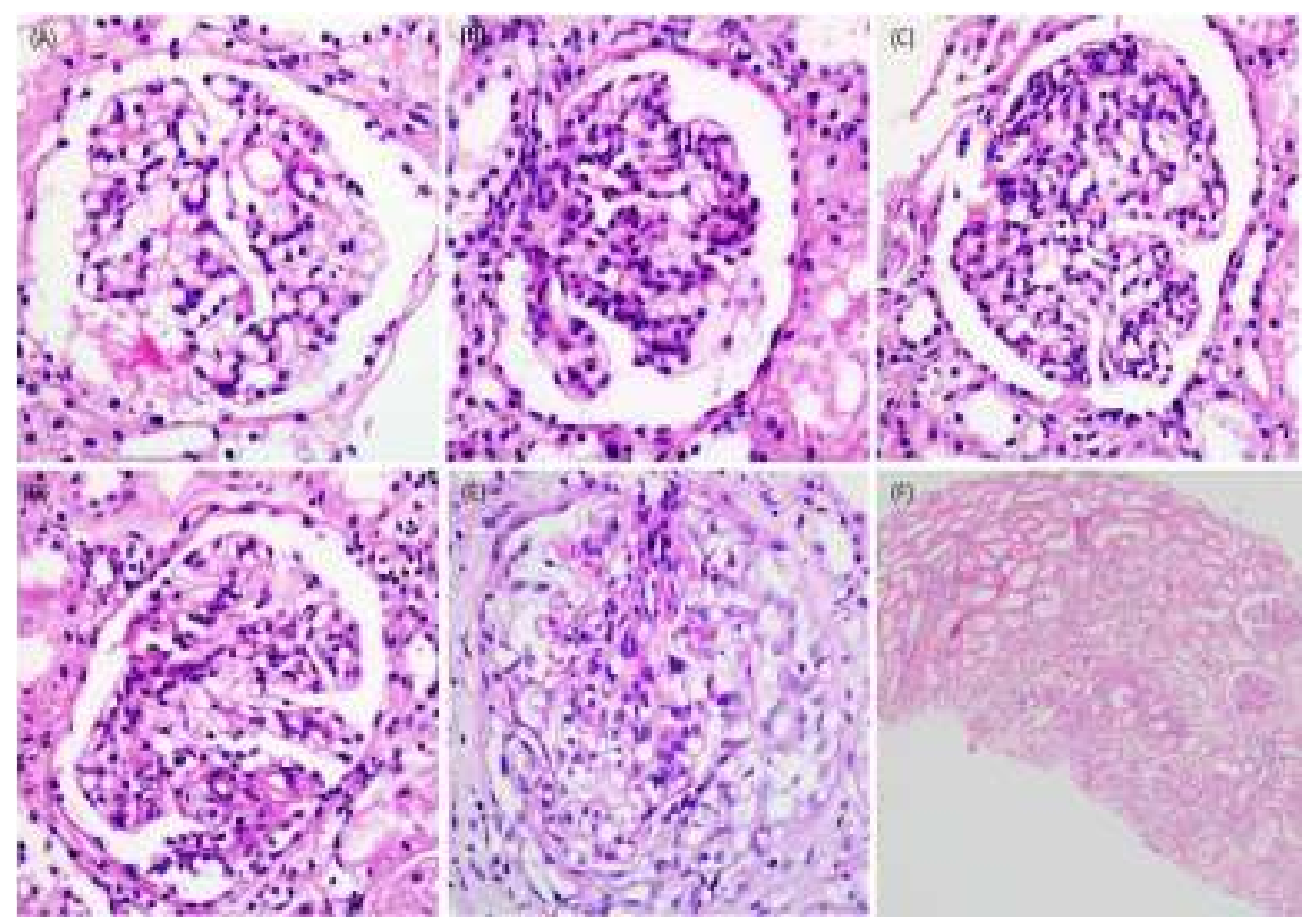

Figure 1. Renal biopsy findings evaluated in IgA nephropathy according to Oxford classification; (A) A mild (less than 50\% glomeruli) mesangial hypercellularity, M0 lesion, (B) Global prominent (more than 50\% of glomeruli) mesangial hypercellularity ( $>4$ mesangial cells in the mesangial areas), M1 lesion, (C) Endocapillary proliferation, E1 lesion, (D) Segmental capillary lumina obliteration and adhesion of the tuft to Bowman's capsule by an increased extracellular matrix, S1 lesion, (E) Glomerular tuft compressed by a cellular crescent formation on the right side of the image, (F) Tubular atrofi and interstitial fibrosis affecting more than $50 \%$ of the renal cortex, T2 lesion.

\section{STATISTICAL ANALYSIS}

Symmetrically distributed variables in the text and tables were shown as means \pm standard deviation. If the distribution was heterogeneous, variables were shown as median (minimum-maximum). Categorical variables are expressed as percentage. Student $t$ test or the Mann-Whitney U test were used to compare continuous variables according to the data distribution. Data distribution was determined by using Kolmogorov-Smirnov test. Homogeneity of variables were determined by using one-way Anova homogeneity of variance test. Chi-square test was used to compare categorical variables. Receiver operating curve (ROC) analysis were plotted to illustrate glomerulosclerosis percentage and serum creatinine best cut-off values for estimation of ESRD and glucocorticoid sensitivity. Cox proportional hazard models were constructed to determine the association between clinical, laboratory and histopathological findings and ESRD. Spearman correlation test was used to find correlation between histopathological parameters and characteristics of patients. $P$ values less than 0.05 were considered to indicate statistical significance. Analyses were performed with Statistical Package for the Social Science (SPSS version 20.0.0, IBM) software for Windows.

\section{RESULTS}

The study included 97 patients $(68 \%$ male, $32 \%$ female) with a median age of $40(20-62)$ years. Patients were divided into two groups according to end stage renal disease (ESRD) development (patients who developed ESRD and did not developed ESRD during the follow up). The frequency of ESRD was $13 \%$ within the median 37 (6-90) months of follow-up. The characteristics of the study population were shown in Table 1. While, age and gender distribution were similar between groups, serum creatinine level, 24-hour urine protein level and need for RRT at first admission were significantly higher in patients 
who developed ESRDduring follow-up ( $\mathrm{p}<0.001$, $p=0.05$ and $p=0.001$, consecutively) (Table 1 ). When we analyzed the histopathological findings of patients' renal biopsies, we observed that percentage of glomerulosclerosis and scores of E1 and $\mathrm{T} 2$ were significantly higher in patients who developed ESRD compared to patients who did not $(63.5 \pm 23$ vs. $23 \pm 21,69 \%$ vs. $38 \%$ and $30 \%$ vs. $2.5 \%, \mathrm{p}<0.001, \mathrm{p}=0.03$ and $\mathrm{p}=0.003$, respectively) (Table 2).

Table 1

The characteristics of study population

\begin{tabular}{|c|c|c|c|c|}
\hline & & \multicolumn{2}{|c|}{ ESRD } & \multirow[b]{2}{*}{$P$ value } \\
\hline & $\begin{array}{c}\text { Total patient } \\
(\mathrm{n}=97)\end{array}$ & $\begin{array}{c}\text { Yes } \\
n=13(13 \%)\end{array}$ & $\begin{array}{c}\text { No } \\
n=84(87 \%)\end{array}$ & \\
\hline Age & $40(20-62)$ & $40(31-50)$ & $41(20-62)$ & 0.5 \\
\hline Gender (male) & $66(68 \%)$ & $9(69 \%)$ & $57(68 \%)$ & 0.9 \\
\hline $\mathrm{Hg}(\mathrm{g} / \mathrm{dl})$ & $13.3 \pm 2$ & $12.3 \pm 2.1$ & $13.5 \pm 2$ & 0.07 \\
\hline Creatinine (mg/dl) & $1.76 \pm 1.5$ & $3.3 \pm 1.8$ & $1.5 \pm 1.1$ & $<0.001$ \\
\hline eGFR $(\mathrm{ml} / \mathrm{min} / 1.73 \mathrm{~m})^{2}$ & $54.6(5.2-145)$ & $24.1(5.2-66.5)$ & $59.7(5.5-145)$ & $<0.001$ \\
\hline Albumin (g/dl) & $3.8 \pm 0.6$ & $3.6 \pm 0.6$ & $3.8 \pm 0.6$ & 0.1 \\
\hline 24 urine protein $(\mathrm{g} / \mathrm{d})$ & $1.9(0.1-15.7)$ & $4.7(0.1-15.7)$ & $1.9(0.1-14)$ & 0.05 \\
\hline $\begin{array}{ll}\text { AKI } & \\
& \text { 0. month } \\
& \text { 6.month } \\
\end{array}$ & $\begin{array}{c}18(18 \%) \\
8(8 \%)\end{array}$ & $\begin{array}{c}3(23 \%) \\
1(8 \%)\end{array}$ & $\begin{array}{c}14(17 \%) \\
7(8 \%)\end{array}$ & $\begin{array}{l}0.6 \\
0.9\end{array}$ \\
\hline $\begin{array}{c}\text { Proteinuria } \mathrm{n}(\%) \\
<1 \mathrm{~g} / \mathrm{d} \\
1-3.5 \mathrm{~g} / \mathrm{d} \\
>3.5 \mathrm{~g} / \mathrm{d}\end{array}$ & $\begin{array}{l}25(26 \%) \\
45(46 \%) \\
27(28 \%)\end{array}$ & $\begin{array}{l}2(15 \%) \\
4(31 \%) \\
7(54 \%)\end{array}$ & $\begin{array}{l}23(27 \%) \\
41(49 \%) \\
20(24 \%)\end{array}$ & $\begin{array}{c}0.5 \\
0.2 \\
\mathbf{0 . 0 4}\end{array}$ \\
\hline RRT & $5(5 \%)$ & $3(23 \%)$ & $2(2 \%)$ & 0.01 \\
\hline Follow up (month) & $37(6-90)$ & $58(8-82)$ & $29(6-90)$ & 0.02 \\
\hline
\end{tabular}

Hg: Hemoglobin, eGFR: estimated glomerular filtration rate, AKI: acute kidney injury, RRT: renal replacement therapy

Table 2

Histopathological findings in kidney biopsy of IgAN patients

\begin{tabular}{|c|c|c|c|c|}
\hline & & \multicolumn{2}{|c|}{ ESRD } & \multirow[b]{2}{*}{$P$ value } \\
\hline & $\begin{array}{c}\text { Total patient } \\
(\mathrm{n}=97)\end{array}$ & $\begin{array}{c}\text { Yes } \\
n=13(13 \%)\end{array}$ & $\begin{array}{c}\text { No } \\
n=84(87 \%)\end{array}$ & \\
\hline Glomerulosclerosis (\%) & $28 \pm 25$ & $63.5 \pm 23$ & $23 \pm 21$ & $<0.001$ \\
\hline Crescent (\%) & $4.7 \pm 9.7$ & $3.03 \pm 5.8$ & $5 \pm 10$ & 0.5 \\
\hline M1 & $57(59 \%)$ & $6(46 \%)$ & $51(61 \%)$ & 0.3 \\
\hline E1 & $41(42 \%)$ & $9(69 \%)$ & $32(38 \%)$ & 0.03 \\
\hline S1 & $67(69 \%)$ & $9(69 \%)$ & $58(69 \%)$ & 0.9 \\
\hline $\mathbf{T}$ & $76(78 \%)$ & $12(92 \%)$ & $64(76 \%)$ & \\
\hline T1 & 70 & 8 & 62 & 0.5 \\
\hline T2 & 6 & $4(30 \%)$ & $2(2.5 \%)$ & 0.003 \\
\hline $\mathbf{C}$ & $27(27 \%)$ & $3(23 \%)$ & $24(29 \%)$ & \\
\hline C1 & 22 & 3 & 19 & 0.9 \\
\hline C2 & 5 & 0 & 5 & 0.4 \\
\hline C3 stain (n) & $59(61 \%)$ & 10 & 49 & \\
\hline $1+$ & $17(18 \%)$ & $2(15 \%)$ & $15(18 \%)$ & 0.8 \\
\hline $2+$ & $25(25 \%)$ & $3(23 \%)$ & $22(26 \%)$ & 0.8 \\
\hline $3+$ & $17(18 \%)$ & $5(39 \%)$ & $12(14 \%)$ & 0.04 \\
\hline Total MEST score & $2.5 \pm 1.1$ & $3.08 \pm 1.04$ & $2.46 \pm 1.16$ & 0.09 \\
\hline Total MEST-C score & $2.87 \pm 1.3$ & $3.3 \pm 1.1$ & $2.81 \pm 1.4$ & 0.2 \\
\hline Kappa stain (n) & $45(46 \%)$ & 6 & 39 & \\
\hline $1+$ & $15(16 \%)$ & $1(8 \%)$ & $14(17 \%)$ & 0.4 \\
\hline $2+$ & $19(19 \%)$ & $2(15 \%)$ & $17(20 \%)$ & 0.6 \\
\hline $3+$ & $11(11 \%)$ & $3(23 \%)$ & $8(10 \%)$ & 0.1 \\
\hline Lambda stain (n) & $46(47 \%)$ & 6 & 40 & \\
\hline $1+$ & $12(12 \%)$ & $1(8 \%)$ & $11(13 \%)$ & 0.5 \\
\hline $2+$ & $18(19 \%)$ & $2(15 \%)$ & $16(19 \%)$ & 0.7 \\
\hline $3+$ & $16(16 \%)$ & $3(23 \%)$ & $13(16 \%)$ & 0.5 \\
\hline K or $\lambda$ stain & $19(20 \%)$ & 0 & $19(23 \%)$ & 0.05 \\
\hline$K$ and $\lambda$ stain negative & $44(45 \%)$ & $7(54 \%)$ & $37(44 \%)$ & 0.5 \\
\hline
\end{tabular}

M1: Mesengial proliferation, E1: Endocapillary hypercellularity, S1: Segmental glomerulosclerosis, T1/2: Tubular atrophy, C1/2: Crescent formation, $\mathbf{\kappa}$ : Kappa chain, $\lambda$ : lambda chain 
We performed ROC analysis for determining the best cut-off value of serum creatinine level at the time of diagnosis to predict ESRD (Table 3). Serum creatinine level of higher than $1.97 \mathrm{mg} / \mathrm{dl}$ was the best cut-off value with $76 \%$ sensitivity, $87 \%$ specificity, $86.7 \%$ negative predictive value and $76.9 \%$ positive predictive value in this sense. The presence of need for RRT at the time of diagnosis, serum creatinine level of higher than $1.97 \mathrm{mg} / \mathrm{dl}$, serum albumin level between $3.5-2.5 \mathrm{gr} / \mathrm{dl}$ or less than $<2.5 \mathrm{gr} / \mathrm{dl}$ and 24-hour urine protein level of higher than $>3.5 \mathrm{~g} /$ day were other clinical and laboratory parameters which were found to be significant predictors of development of ESRD during follow-up [HR:6.340 (95\% Cl 1.599-25.140), HR:13.923 (95\% Cl 3.825-60.673), HR:4.251 (95\% Cl 1.005-17.972), HR:10.592 (95\% Cl 1.636-68.590) and HR:4.314 (95\% Cl 1.010-21.226)] (Table 3). A separate statistical analysis was carried out for determining the factors affecting the corticosteroid response of 52 patients with IgAN who were given standard KDIGO treatment (Table 3). None of the clinical or laboratory parameters examined including age, gender, the presence of AKI at the time of diagnosis or development of AKI on follow-up, serum albumin or creatinine levels or 24-hour urine protein level were found to be significant predictor of steroid treatment sensitivity (Table 3 ). When we look at the predictive value of histopathological features for development of ESRD and responsiveness to steroid treatment, the percentage of glomerulosclerosis higher than 53\% was found to be the best cut-off value with $76 \%$ sensitivity, $90 \%$ specificity, $88 \%$ negative predictive value and $77 \%$ positive predictive value on ROC analysis to predict the development of ESRD. Cox regression analysis also showed that the percentage of glomerulosclerosis higher than $53 \%$ is a predictor of ESRD [HR: $11.322(95 \% \mathrm{Cl}$ 3.093-41.443) and $p<0.001]$. Also, T2 score of Oxford classification and total MEST-C score higher than two were other histopathological predictors of ESRD [HR:72.514 (95\% Cl 6.887-763.562) and HR:2.086 (95\% Cl 1.161-3.748), $\mathrm{p}<0.001$ and $\mathrm{p}=0.01]$ in all patients (Table 4). Immunofluorescence staining of $\mathrm{C} 3, \mathrm{~K}$ or $\lambda$ were not found to be associated with development of ESRD. When we look at the histopathological features which may affect corticosteroid treatment response, we observed that only $\mathrm{T} 1$ and $\mathrm{T} 2$ scores of Oxford classification showed effects on steroid sensitivity of the patients [HR:0.046 (95\% Cl 0.006-0.335) and HR: 0.055 (95\% C10.009-0.339) $\mathrm{p}=0.002$ and $\mathrm{p}=0.002] . \mathrm{T} 1$ or T2 (T1/T2) scores have a positive correlation with S1 score, higher serum creatinine levels and higher 24-hour urine protein levels $(\mathrm{p}=0.00, \mathrm{CC}: 0.33$; $\mathrm{p}=0.008$, CC:0.27; and $\mathrm{p}=0.007, \mathrm{CC}: 0.28)($ Table 5).

Table 3

Cox regression analysis of clinical and laboratory parameters for ESRD development and steroid treatment sensitivity

\begin{tabular}{|c|c|c|c|c|c|c|}
\hline \multicolumn{4}{|c|}{ Risk analysis for ESRD } & \multicolumn{3}{|c|}{ Steroid treatment sensitivity indicators ${ }^{*}$} \\
\hline & $\begin{array}{c}\text { Hazard } \\
\text { ratio }\end{array}$ & $\begin{array}{c}95 \% \text { confidence } \\
\text { interval }\end{array}$ & $P$ value & $\begin{array}{c}\text { Hazard } \\
\text { ratio }\end{array}$ & $95 \%$ confidence interval & $\begin{array}{c}P \\
\text { value }\end{array}$ \\
\hline age & 0.967 & $0.904-1.035$ & 0.3 & 0.995 & $0.957-1.035$ & 0.8 \\
\hline Gender & 0.448 & $0.124-1.622$ & 0.2 & 0.822 & $0.382-1.768$ & 0.6 \\
\hline $\begin{array}{l}\text { AKI } \\
\text { 0. month } \\
\text { 6. month }\end{array}$ & $\begin{array}{l}1.616 \\
4.118\end{array}$ & $\begin{array}{c}0.439-5.949 \\
0.418-40.531\end{array}$ & $\begin{array}{l}0.5 \\
0.2\end{array}$ & $\begin{array}{l}1.403 \\
1.165\end{array}$ & $\begin{array}{l}0.460-4.281 \\
0.489-2.775\end{array}$ & $\begin{array}{l}0.5 \\
0.7\end{array}$ \\
\hline RRT $^{* * *}$ & 6.340 & $1.599-25.140$ & 0.009 & & & \\
\hline Crea $>1.97^{* *}(\mathrm{mg} / \mathrm{dl})$ & 13.923 & $3.825-50.673$ & $<0.001$ & 1.907 & $0.717-5.073$ & 0.2 \\
\hline $\begin{array}{l}\text { Albumin }(\mathrm{g} / \mathrm{dl}) \\
>4 \\
3.5-4 \\
2.5-3.5 \\
<2.5 \\
\end{array}$ & $\begin{array}{c}\text { Ref } \\
1.597 \\
4.251 \\
10.592 \\
\end{array}$ & $\begin{array}{c}\text { Ref } \\
0.308-7.770 \\
1.005-17.972 \\
1.636-68.590 \\
\end{array}$ & $\begin{array}{c}\text { Ref } \\
0.6 \\
\mathbf{0 . 0 5} \\
\mathbf{0 . 0 1}\end{array}$ & $\begin{array}{l}\text { Ref } \\
1.310 \\
1.791 \\
2.114 \\
\end{array}$ & $\begin{array}{c}\text { Ref } \\
0.505-3.399 \\
0.662-4.844 \\
0.436-10.257 \\
\end{array}$ & $\begin{array}{l}\text { Ref } \\
0.6 \\
0.3 \\
0.4\end{array}$ \\
\hline $\begin{array}{l}\text { Proteinuria }(\mathrm{g} / \mathrm{d}) \\
<1 \\
1-3.5 \\
>3.5\end{array}$ & $\begin{array}{c}\text { Ref } \\
0.948 \\
4.314\end{array}$ & $\begin{array}{c}\text { Ref } \\
0.173-5.205 \\
1.010-21.226\end{array}$ & $\begin{array}{l}\text { Ref } \\
0.9 \\
\mathbf{0 . 0 5}\end{array}$ & $\begin{array}{c}\text { Ref } \\
0.801 \\
0.722\end{array}$ & $\begin{array}{c}\text { Ref } \\
0.265-2.416 \\
0.214-2.433\end{array}$ & $\begin{array}{l}\text { Ref } \\
0.7 \\
0.6\end{array}$ \\
\hline IS treatment & 0.132 & $0.013-1.338$ & 0.08 & & & \\
\hline
\end{tabular}

ESRD: end stage renal disease, AKI: acute kidney injury, RRT: renal replacement therapy, Crea: creatinine, IS: immunosuppressive

${ }^{*} 52$ patients, who used steroid treatment, were analyzed

${ }^{* *}$ roc analysis creatinine 1.97 ; sens $76 \%$ spes 87 uac0.891 npv: 86.7 ppv: 76.9

${ }^{* * *}$ Patients were not evaluated due to combined immune suppressive treatment 
Table 4

Cox regression analysis of histopathological findings on renal biopsy for ESRD development and steroid treatment sensitivity

\begin{tabular}{|c|c|c|c|c|c|c|}
\hline \multicolumn{4}{|c|}{ Risk analysis for ESRD } & \multicolumn{3}{|c|}{ Steroid treatment sensitivity indicators ${ }^{*}$} \\
\hline & $\begin{array}{c}\text { Hazard } \\
\text { ratio }\end{array}$ & $\begin{array}{c}95 \% \text { confidence } \\
\text { interval }\end{array}$ & P value & $\begin{array}{c}\text { Hazard } \\
\text { ratio }\end{array}$ & $95 \%$ confidence interval & $P$ value \\
\hline Glomsclerosis $>\mathbf{5 3 \%}{ }^{* *}$ & 11.322 & $3.093-41.443$ & $<\mathbf{0 . 0 0 1}$ & 0.513 & $0.120-2.185$ & 0.4 \\
\hline Crescent & 1.037 & $0.963-1.117$ & 0.3 & 1.017 & $0.986-1.048$ & 0.3 \\
\hline M1 & 0.742 & $0.248-2.220$ & 0.6 & 1.574 & $0.734-3.378$ & 0.2 \\
\hline E1 & 2.048 & $0.622-6.744$ & 0.2 & 0.750 & $0.354-1.593$ & 0.4 \\
\hline S1 & 1.832 & $0.552-6.081$ & 0.3 & 1.232 & $0.546-2.780$ & 0.6 \\
\hline $\mathbf{T}$ & & & & & & \\
\hline T1 & 4.197 & $0.523-33.698$ & 0.2 & 0.046 & $0.006-0.335$ & 0.002 \\
\hline $\mathbf{T 2}$ & 72.514 & $6.887-763.562$ & $<\mathbf{0 . 0 0 1}$ & 0.055 & $0.009-0.339$ & 0.002 \\
\hline C1 or C2 & 3.115 & $0.697-13.912$ & 0.1 & 1.017 & $0.986-1.048$ & 0.3 \\
\hline Total MEST score $(\geq 2)$ & 3.632 & $0.471-28.014$ & 0.2 & 1.177 & $0.504-2.749$ & 0.7 \\
\hline $\begin{array}{l}\text { Total MEST-C score } \\
(\geq 2)\end{array}$ & 2.086 & $1.161-3.748$ & 0.01 & 1.185 & $0.904-1.552$ & 0.2 \\
\hline $\begin{array}{l}\text { C3 stain } \\
1+ \\
2+ \\
3+\end{array}$ & $\begin{array}{l}0.706 \\
1.430 \\
1.154 \\
\end{array}$ & $\begin{array}{l}0.105-4.756 \\
0.273-7.491 \\
0.248-5.374 \\
\end{array}$ & $\begin{array}{l}0.7 \\
0.6 \\
0.8 \\
\end{array}$ & $\begin{array}{l}1.047 \\
0.872 \\
0.266 \\
\end{array}$ & $\begin{array}{l}0.372-2.951 \\
0.328+2.320 \\
0.057-1.233 \\
\end{array}$ & $\begin{array}{c}0.9 \\
0.8 \\
0.09 \\
\end{array}$ \\
\hline $\begin{array}{l}\text { Kappa stain } \\
1+ \\
2+ \\
3+\end{array}$ & $\begin{array}{l}0.343 \\
1.120 \\
1.317\end{array}$ & $\begin{array}{l}0.042-2.812 \\
0.222-5.649 \\
0.339-5.122\end{array}$ & $\begin{array}{l}0.3 \\
0.8 \\
0.6\end{array}$ & $\begin{array}{l}0.523 \\
0.522 \\
0.913 \\
\end{array}$ & $\begin{array}{l}0.171-1.596 \\
0.152-1.794 \\
0.291-2.861\end{array}$ & $\begin{array}{l}0.3 \\
0.3 \\
0.9\end{array}$ \\
\hline $\begin{array}{l}\text { Lambda stain } \\
1+ \\
2+ \\
3+\end{array}$ & $\begin{array}{l}0.292 \\
1.022 \\
0.777\end{array}$ & $\begin{array}{c}0.035-2.411 \\
0.199-5.245 \\
0197-3.064\end{array}$ & $\begin{array}{l}0.2 \\
0.9 \\
0.7\end{array}$ & $\begin{array}{l}0.625 \\
0.572 \\
0.617\end{array}$ & $\begin{array}{l}0.201-1.944 \\
0.189-1.732 \\
0.199-1.910\end{array}$ & $\begin{array}{l}0.4 \\
0.3 \\
0.4\end{array}$ \\
\hline K or $\lambda$ stain & 0.033 & $0.000-18.372$ & 0.3 & 0.246 & $0.033-1.821$ & 0.2 \\
\hline$K$ and $\lambda$ stain negative & 1.667 & $0.545-5.102$ & 0.4 & 1.672 & $0.773-3.620$ & 0.2 \\
\hline
\end{tabular}

M1: Mesengial proliferation, E1: Endocapillary hypercellularity, S1: Segmental glomerulosclerosis, T1/2: Tubular atrophy, C1/2: Crescent formation, $\boldsymbol{\kappa}:$ Kappa chain, $\lambda$ : lambda chain

* 52 patients, who used steroid treatment, were analyzed

${ }^{* *}$ roc analysis was used; glomerulosclerosis 53\% sen:76 spes:90 uac: 0.889 npv:88 ppv:77

Table 5

Nonparametric Spearman correlations coefficients among histopathological parameters and clinical findings in patients with IgAN

\begin{tabular}{|c|c|c|c|c|c|c|c|c|c|c|c|c|}
\hline & M1 & E1 & S1 & $T 1 / 2$ & $\mathrm{C} 1 / 2$ & K stain & $\lambda$ stain & C3 stain & Age & Crea. & Albumin & 24-UP \\
\hline \begin{tabular}{|l|} 
M1 \\
\end{tabular} & 1 & -0.004 & 0.119 & 0.213 & 0.058 & -0.123 & $-0.225^{1}$ & -0.065 & 0.143 & -0.051 & -0.086 & 0.115 \\
\hline E1 & & 1 & 0.076 & 0.062 & 0.006 & 0.197 & 0.077 & $0.274^{2}$ & 0.123 & 0.072 & -0.121 & 0.197 \\
\hline S1 & & & 1 & $0.334^{3}$ & 0.044 & 0.151 & 0.095 & 0.045 & -0.115 & 0.093 & -0.141 & 0.129 \\
\hline T1/2 & & & & 1 & 0.177 & 0.144 & -0.077 & -0.005 & -0.066 & $0.268^{2}$ & $-0.237^{1}$ & $0.275^{2}$ \\
\hline $\mathrm{C} 1 / 2$ & & & & & 1 & 0.115 & 0.032 & -0.109 & -0.170 & 0.032 & $-0.248^{1}$ & 0.115 \\
\hline K stain & & & & & & 1 & $0.708^{3}$ & $0.455^{3}$ & -0.188 & -0.064 & 0.078 & -0.176 \\
\hline$\lambda$ stain & & & & & & & 1 & $0.276^{2}$ & -0.181 & -0.163 & 0.129 & -0.132 \\
\hline C3 stain & & & & & & & & 1 & -0.063 & 0.124 & -0.013 & 0.027 \\
\hline Age & & & & & & & & & 1 & 0.152 & -0.144 & 0.069 \\
\hline Creatinine & & & & & & & & & & 1 & -0.199 & 0.163 \\
\hline Albumin & & & & & & & & & & & 1 & $0.491^{3}$ \\
\hline 24-UP & & & & & & & & & & & & 1 \\
\hline
\end{tabular}

M1: Mesengial proliferation, E1: Endocapillary hypercellularity, S1: Segmental glomerulosclerosis, T1/2: Tubular atrophy, C1/2: Crescent formation, Crea: Creatinine 24-UP: 24 hour urine protein $(\mathbf{g} / \mathbf{d}), \mathbf{\kappa}$ : Kappa chain, $\lambda$ : lambda chain

There are many clinical and histopathological criterion used in the literature to determine the prognosis of IgAN [4]. However, these criteria do not reach a statistical significance for predicting renal prognosis in every study [3]. We performed Cox regression analysis by thinking that it may be more valuable to evaluate the clinical and histopathological findings together to determine the prognosis in these patients. The results of this analysis are shown in Figure 2. 

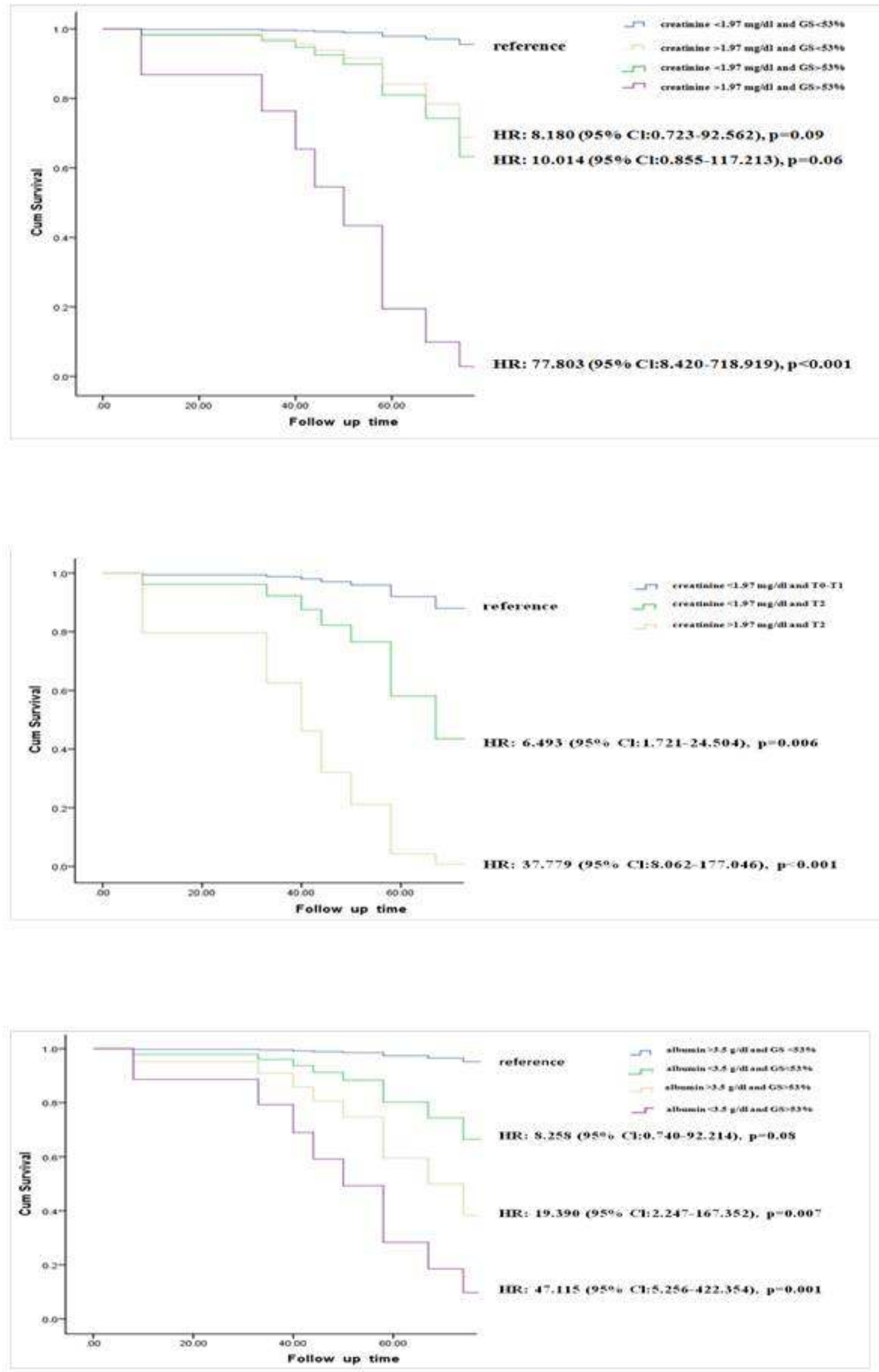

Figure 2. Cox regression analysis of laboratory and histopathological findings of IgAN patients for ESRD. 


\section{DISCUSSION}

IgAN is one of the most common primary glomerulonephritides and is a leading cause of ESRD. Furthermore, it is a heterogeneous disease and predicting the prognosis of IgAN is challenging. We investigated the histopathological and clinical parameters that could predict the development of ESRD and the response to corticosteroid treatment in IgAN patients in this study.

Data from the European Validation Study of the Oxford Classification of IgAN (VALIGA) study demonstrated that $\mathrm{M}, \mathrm{S}$ and T lesions of the classification independently predict the loss of eGFR and are associated with poor renal survival [16]. Following this study, many other studies partially or completely validated the independent association of MEST score with renal outcomes in IgAN patients [5, 17]. Katafuchi R. et al. designed a study with 702 patients with IgAN and they did not find any association between $\mathrm{M}, \mathrm{E}$ and $\mathrm{S}$ lesions and the development of ESRD, however, T lesion was a predictor of ESRD [18]. On the other hand, a meta-analysis of 16 retrospective cohort studies showed that separately all MEST-C lesions except E lesion were strong predictors of ESRD [19]. Although, the literature data for validation of MEST score is very variable and controversial, the common point of all studies is the fact that $\mathrm{T}$ lesion is the most important and strongest factor in predicting ESRD. In our study, we also showed that the T lesion was a strong predictor of ESRD and has a positive correlation with serum creatinine level and 24-hour urine protein level and has a negative correlation with serum albumin level. Other lesions of Oxford classification were not found to be associated with ESRD in our study. Lee MJ et al. showed that the presence of crescent in a renal biopsy was not related to the development of ESRD [20]. This observation was confirmed by Greece registry in 2018 which includes 457 patients [20]. Similarly, we also did not find any relationship between the presence of crescents in the biopsy and the renal survival in this study.

In the literature, higher than two points of MEST score is accepted as an important predictor of ESRD [21]. Although, we were unable to show the predictive value of MEST score for renal prognosis in our study, we found that higher than two points of MEST-C score seems to be a predictor of ESRD in patients with IgAN. This situation can be explained by the fact that patients with crescent in their biopsies were treated with more aggressive treatment modalities.
Similar to contradictory value of lesions of Oxford classification, the effect of immunofluorescence staining results of renal biopsy in IgAN prognosis is also not clear [22, 23]. Abe K. et al. demonstrated that $\mathrm{C} 3$ is synthesized in glomerular resident cells, including mesangial cells and glomerular epithelial cells and the degree of $\mathrm{C} 3$ expression correlated positively with the degree of mesangial expansion in IgAN [22]. Another study showed that $\mathrm{C} 3$ positivity is associated with glomerulosclerosis, endocapillary proliferation and tubular atrophy in IgAN [23]. Although, our study did not show an association between development of ESRD and the intensity of C3 staining, a positive correlation was found between $\mathrm{C} 3$ staining and $\mathrm{E}$ lesion.

Although, the optimal use of immunosuppressive therapies in IgAN is controversial [24, 25], it has not been shown that corticosteroid treatment decreases the risk of ESRD development in our study. In addition, we also could not show that immunesuppressive drugs prevent the development of renal failure in IgAN patients. This situation can be explained by the retrospective nature of the study and the low number of cases included. Similar to our results, Yoon CY. et al. reported that corticosteroid treatment was not associated with improved clinical outcomes in IgAN patients [26]. When the clinical and histopathological findings that could affect the patients' response to corticosteroid treatment was analyzed, we showed that only the $\mathrm{T}$ lesion seemed to predict the poor response to therapy. Factors that are reported to affect the corticosteroid response of the patients in the literature are controversial [27, 28]. Ruan Y. et al. showed that only endocapillary hypercellularity could predict steroid treatment responsiveness [27], on the other hand, Choi et al reported that MEST score has no predictive value in this regard [28].

The increase in serum creatinine and proteinuria levels in IgAN are defined as risk factors for ESRD $[4,20]$. Our results showed that serum creatinine level of higher than $1.97 \mathrm{mg} / \mathrm{dl}$ at the time of renal biopsy was a strong predictor of ESRD development with high sensitivity and specificity. We also demonstrated that proteinuria of more than $3.5 \mathrm{~g}$ /day is a significant predictor for ESRD. However, there are studies which showed that quantifying proteinuria over long periods of follow-up, up to three years following biopsy, is necessary to more accurately predict ESRD development [29]. This finding was supported by the results of meta-analysis performed by Inker et al. [30]. Therefore, the level of proteinuria as a reliable indicator for ESRD alone is questionable. 
In brief, available clinical and histopathological parameters are insufficient to determine the prognosis of IgAN when they are evaluated individually. The literature findings do not provide a clear outcome about the effectiveness of clinical markers and histopathological findings on renal survival. For now, higher serum creatinine levels at the time of biopsy and the $\mathrm{T}$ score of Oxford classification seem to be the most reliable markers for IgAN prognosis. However, we thought that the use of clinical and histopathological markers together will be more useful in determining the prognosis of IgAN. In our multivariate cox regression analysis, we showed that the individual clinical and histopathological parameters have low efficacy in determining the prognosis in IgAN, however these parameters became very strong indicators when they are analyzed in combination. The study has some limitations. First, the low number of cases who received the standard treatment protocol according to KDIGO guideline and the relatively short follow-up times of the patients were the main limitations of this study. Second, because of the retrospective nature of the study, blood pressure control and macroscopic hematuria, which may affect the prognosis of the disease, could not be investigated.

\section{CONCLUSION}

IgA nephropathy is a heterogeneous disease that requires clinical and histopathological features to be evaluated together, but not individually, to determine renal survival. A serum creatinine level of higher than $1.97 \mathrm{mg} / \mathrm{dl}$ at the time of biopsy, the presence of more than $53 \%$ glomerulosclerosis or a high $\mathrm{T}$ score in renal biopsy seem to be important and strong risk factors for ESRD development in IgAN patients.

Introducere. Nefropatia cu IgA este o boală heterogenă cu caracteristici clinice şi histopatologice diferite. Obiectivul studiului a fost de a investiga efectele clasificării Oxford asupra acestor pacienţi.

Metode. A fost realizat un studiu retrospectiv observaţional din 2013 până in 2017. 97 de pacienţi urmăriţi pe o perioadă mai lungă de 6 luni au fost evaluaţi.

Rezultate. 97 de pacienţi (mediană 40 ani, 68\% bărbaţi) au fost înrolaţi în studiu. $13 \%$ aveau boală terminală de rinichi (ESRD) şi durata de urmărire a fost in medie 37 luni. Predictori pentru ESRD au fost necesitatea transplantului renal la momentul diagnosticului, nivelul creatininei serice peste $1,97 \mathrm{mg} / \mathrm{dl}$, albumina serică peste 3,5 g/24 ore sau peste 3,5 $\mathrm{g} / \mathrm{zi}$, un grad de glomeruloscleroză peste $53 \%$ scor. MEST-C peste 2.

Concluzii. Nefropatia cu IgA este o boală heterogenă ce necesită integrare clinică şi histopatologică pentru tratament.

Correspondence to: Hasan Haci Yeter, Department of Nephrology, Gazi University Medical School, ANKARA

Email:hasanyeter@hotmail.com

Tel: + 905542397449

Orchid: 0000-0002-5787-1048

Conflict of interest disclosure: All of the authors declare that they have no conflict of interest

Acknowledgements: All of the authors declare that there is no funding.

\section{REFERENCES}

1. LI L-S, LIU Z-H, Epidemiologic data of renal diseases from a single unit in China: analysis based on 13,519 renal biopsies. Kidney Int. 2004; 66(3): p. 920-923.

2. REICH HN, TROYANOV S, SCHOLEY JW, CATTRAN DC, Remission of proteinuria improves prognosis in IgA nephropathy. J Am Soc Nephrol. 2007; 18(12): p. 3177-3183.

3. BARBOUR SJ, REICH HN, Risk stratification of patients with IgA nephropathy. Am J Kidney Dis. 2012; 59(6): p. 865-873.

4. BARBOUR S, REICH H, An update on predicting renal progression in IgA nephropathy. Curr Opin Nephrol Hypertens. 2018; 27(3): p. 214-220.

5. CATTRAN DC, COPPO R, COOK HT, FEEHALLY J, ROBERTS IS, TROYANOV S, et al., The Oxford classification of IgA nephropathy: rationale, clinicopathological correlations, and classification. Kidney Int. 2009; 76(5): p. 534-545. 
6. TRIMARCHI H, BARRATT J, CATTRAN D, COOK H, COPPO R, HAAS M, et al., IgAN Classification Working Group of the International IgA Nephropathy Network and the Renal Pathology Society; Kidney Int. 2016;91:1014-1021

7. CATTRAN D, COPPO R, COOK H, FEEHALLY J, ROBERTS I, TROYANOV S, et al., Working Group of the International IgA Nephropathy Network and the Renal Pathology Society. The Oxford classification of IgA nephropathy: Rationale, clinicopathological correlations, and classification. Kidney Int. 2009; 76: p. 534-545.

8. SOARES MF, An update on pathology of IgA nephropathy. J Bras Nephrol.2016; 38(4): p. 435-440.

9. BELLUR SS, LEPEYTRE F, VOROBYEVA O, TROYANOV S, COOK HT, ROBERTS IS, et al., Evidence from the Oxford Classification cohort supports the clinical value of subclassification of focal segmental glomerulosclerosis in IgA nephropathy. Kidney Int. 2017; 91(1): p. 235-243.

10. TRIMARCHI H, BARRATT J, CATTRAN DC, COOK HT, COPPO R, HAAS M, et al., Oxford classification of IgA nephropathy 2016: an update from the IgA nephropathy classification working group. Kidney Int. 2017; 91(5): p. 1014-1021.

11. HAAS M, VERHAVE JC, LIU Z-H, ALPERS CE, BARRATT J, BECKER JU, et al., A multicenter study of the predictive value of crescents in IgA nephropathy. J Am Soc Nephrol. 2017; 28(2): p. 691-701.

12. RADHAKRISHNAN J, CATTRAN DC, The KDIGO practice guideline on glomerulonephritis: reading between the (guide) lines-application to the individual patient. Kidney Int. 2012; 82(8): p. 840-856.

13. CATTRAN DC, FEEHALLY J, COOK HT, LIU ZH, FERVENZA FC, MEZZANO SA, et al., Kidney disease: improving global outcomes (KDIGO) glomerulonephritis work group. KDIGO clinical practice guideline for glomerulonephritis. Kidney Int Suppl. 2012; 2(2): p. 139-274.

14. KOBAYASHI Y, HIKI Y, FUJII K, KUROKAWA A, TATENO S, Moderately proteinuric IgA nephropathy: prognostic prediction of individual clinical courses and steroid therapy in progressive cases. Nephron. 1989; 53(3): p. 250-256.

15. TSUNODA R, USUI J, HOSHINO J, FUJII T, SUZUKI S, TAKAICHI K, et al., Corticosteroids pulse therapy and oral corticosteroids therapy for IgA nephropathy patients with advanced chronic kidney disease: results of a multicenter, large-scale, long-term observational cohort study. BMC Nephrol. 2018; 19(1): p. 222.

16. COPPO R, TROYANOV S, BELLUR S, CATTRAN D, COOK HT, FEEHALLY J, et al., Validation of the Oxford classification of IgA nephropathy in cohorts with different presentations and treatments. Kidney Int. 2014; 86(4): p. 828-836.

17. ALAMARTINE E, SAURON C, LAURENT B, SURY A, SEFFERT A, MARIAT C, The use of the Oxford classification of IgA nephropathy to predict renal survival. Clin J Am Soc Nephrol, 2011; 6:2384-2388

18. KATAFUCHI R, NINOMIYA T, NAGATA M, MITSUIKI K, HIRAKATA H, Validation study of Oxford classification of IgA nephropathy: the significance of extracapillary proliferation. Clin J Am Soc Nephrol. 2011; 6(12): p. 2806-2813.

19. LV J, SHI S, XU D, ZHANG H, TROYANOV S, CATTRAN DC, et al., Evaluation of the Oxford Classification of IgA nephropathy: a systematic review and meta-analysis. Am J Kidney Dis. 2013; 62(5): p. 891-899.

20. STANGOU M, PAPASOTIRIOU M, XYDAKIS D, OIKONOMAKI T, MARINAKI S, ZERBALA S, et al., IgA nephropathy in Greece: data from the registry of the Hellenic Society of Nephrology. Clin Kidney J. 2017; 11(1): p. 38-45.

21. MAIXNEROVA D, REILY C, BIAN Q, NEPRASOVA M, NOVAK J, TESAR V, Markers for the progression of IgA nephropathy. J Nephrol. 2016; 29(4): p. 535-541.

22. ABE K, MIYAZAKI M, KOJI T, FURUSU A, SHIOSHITA K, TSUKASAKI S, et al., Intraglomerular synthesis of complement C3 and its activation products in IgA nephropathy. Nephron. 2001; 87(3): p. 231-239.

23. MONTINARO V, GESUALDO L, RANIERI E, MONNO R, GRANDALIANO G, SCHENA FP, Renal cortical complement C3 gene expression in IgA nephropathy. J Am Soc Nephrol. 1997; 8(3): p. 415-425.

24. POZZI C, Treatment of IgA nephropathy. J Nephrol. 2016; 29(1): p. 21-25.

25. RAUEN T, EITNER F, FITZNER C, SOMMERER C, ZEIER M, OTTE $\mathrm{B}$, et al., Intensive supportive care plus immunosuppression in IgA nephropathy. N Eng J Med. 2015; 373(23): p. 2225-2236.

26. YOON C-Y, CHANG TI, KANG EW, LIM BJ, KIE JH, KEE YK, et al., Clinical usefulness of the Oxford classification in determining immunosuppressive treatment in IgA nephropathy. Ann Med. 2017; 49(3): p. 217-229.

27. RUAN Y, CHEN W, LI Z, TANG X, LI J, YU X, et al., Role of immunosuppressive therapy and predictors of therapeutic effectiveness and renal outcome in IgA nephropathy with proteinuria. Arch Med Sci. 2015; 11: 332.

28. CHOI S, LEE D, JEONG K, MOON J, LEE S, LEE T, et al., Prognostic relevance of clinical and histological features in IgA nephropathy treated with steroid and angiotensin receptor blockers. Clin Nephrol. 2009; 72(5): p. 353-359.

29. BARTOSIK LP, LAJOIE G, SUGAR L, CATTRAN DC, Predicting progression in IgA nephropathy. Am J Kidney Dis. 2001; 38(4): p. 728-735.

30. INKER LA, MONDAL H, GREENE T, MASASCHI T, LOCATELLI F, SCHENA FP, et al., Early change in urine protein as a surrogate end point in studies of IgA nephropathy: an individual-patient meta-analysis. Am J Kidney Dis. 2016; 68(3): p. $392-401$.

Received $19^{\text {th }}$ April 2020 